\title{
Hydrogen Sulphide Exposure on Lipid Peroxidation and Antioxidant Enzymes in Fishes
}

\author{
Sreejai R. ${ }^{1}$, Chithra V.S. ${ }^{2}$ \\ Research Department of Zoology, St. Stephen's College, Maloor College P.O., Pathanapuram, Kerala, India 699695
}

\begin{abstract}
Oxidative stress may ensue when the ability to buffer against reactive oxygen species (ROS) is exceeded either by excessive production of ROS or by depletion of antioxidant. This can alter cellular redox-poise and initiate a variety of responses via intracellular pathways. Hydrogen sulphide is a toxic gas which is harmful to aquatic organisms especially in the unionized form. In the present study two different concentrations of hydrogen sulphide is used for the toxicity assay in two test groups of Oreochromis mossambicus in time intervals of 12hrs, $24 \mathrm{hrs}, 48 \mathrm{hrs}, 72 \mathrm{hrs}$ and $96 \mathrm{hrs}$. With respect to the $\mathrm{H}_{2} \mathrm{~S}$ concentration and duration of exposure, alterations were recorded in the concentration of lipid peroxidation products and antioxidants in the various organs of the test fishes. Malondialdehyde content increases in liver, gill, kidney and brain on exposure to hydrogen sulphide up to 48hrs and then the MDA content showed steady value up to $98 \mathrm{hrs}$ experimental period. Brain and kidney showed the maximum increase in concentration of reduced glutathione in initial stages (48 hrs) of hydrogen sulphide treatment. The gradual decrease in concentration of GSH in the tissues of $H_{2} S$ exposed fishes after 48 hrs up to $96 \mathrm{hrs}$ compared to the control shows the loss of adaptive mechanisms and the oxidation of GSH to GSSG. Slight increase in the activity of glutathione-S-transferase and decrease in activity of glutathione peroxidase demonstrated the incapability of the vital organs in neutralizing the peroxides generated in the oxidative stress condition.
\end{abstract}

Keywords: Oxidative stress, lipid peroxidation, hydrogen sulphide, antioxidants, malondialdehyde

\section{Introduction}

Hydrogen sulphide is a potentially lethal gas produced by anaerobic decomposition of protein and other sulfur containing organic matter. It can also be produced either by the decomposition of organic effluents from municipal sewage and many industries. It is also formed in the coir retting process usually done in estuaries using coconut husk. It may occur naturally at levels which can be inimical to fish production and survival ${ }^{1}$.The toxic effects of hydrogen sulphide are based on its property as a chemical asphyxiate. It binds to the mitochondrial enzyme cytochrome oxidase, blocking oxidative phosphorylation and ATP production. This leads to anaerobic metabolism and development of lactic acidosis. Oxidative stress can be defined as an elevation in the steady state concentration of reactive oxygen species, which occur when the balance between the mechanisms triggering oxidative conditions and cellular antioxidant is impaired. The enzymatic and non- enzymatic antioxidant defense mechanisms work together to counter oxidative stress. In this study, an attempt has been made to evaluate the effect of hydrogen sulphide exposure at two different concentrations on the fresh water fish, Oreochromis mossambicus. Also aims to find out the oxidative stress in fishes by measuring the concentration of lipid peroxidation products, and the changes in the activities of antioxidant enzymes in liver, gill, kidney and brain tissues.

\section{Materials and Methods}

Healthy specimens of Oreochromis mossambicus (Tilapia) were collected from fish rearing ponds in Thiruvanathapuram and maintained in the laboratory in large glass aquaria containing weathered, well aerated tap water for two weeks. These fishes were treated with potassium permanganate solution $(0.5 \% \mathrm{w} / \mathrm{v})$ in order to get rid of infectious organisms. Acclimation was done at room temperature $\left(28 \pm 2^{0} \mathrm{C}\right)$ and the fishes were exposed to the natural day and night cycle. The fishes were fed with standard food pellets adlibitum. The physico-chemical characteristics (temperature, dissolved oxygen, $\mathrm{pH}$, total alkalinity, total ammonia nitrogen, and total hardness) of the aquarium water in the tanks were monitored throughout the experimental study period.

Hydrogen sulphide was prepared by reacting dilute hydrochloric acid with ferrous sulphide sticks in a Kipp's Apparatus. The gas flow was regulated by using a flow meter. Exploratory test were conducted initially to assess the range of concentrations suitable for the diagnostic test. The concentrations of hydrogen sulphide used for definitive test in aquarium water was assessed as $4.9 \mathrm{mg} / \mathrm{L}$ on two minute passage of the gas and $6.6 \mathrm{mg} / \mathrm{L}$ in five minute passage of gas. The lethal concentration of hydrogen sulphide for $50 \%$ fish death $\left(\mathrm{LC}_{50} 24 \mathrm{hr}\right)$ was calculated as $6.6 \mathrm{mg} / \mathrm{L}$.

Healthy female fishes of uniform body weight $(30 \pm 5 \mathrm{gm})$ and body length $(12 \pm 14 \mathrm{~cm})$ were selected for the study. The fishes were divided into three groups $\left(T_{1}, T_{2} \& C\right)$ with ten fishes in each group and maintained in aquarium water without feed for 12 hours before exposure to $\mathrm{H}_{2} \mathrm{~S}$. The fishes in $\mathrm{T}_{1}$ and $\mathrm{T}_{2}$ groups were experimentally exposed to two different concentrations of hydrogen sulphide $(4.9 \mathrm{mg} / \mathrm{L}$ and $6.6 \mathrm{mg} / \mathrm{L})$ under controlled conditions. The third group (C) served as control and the fishes were maintained in aquarium water without hydrogen sulphide. Two replicate experiments for each group were also conducted.

The test and control group fishes were sacrificed after 12 hrs, 24 hrs, 48 hrs, 72 hrs and 92 hrs experimental duration and the tissues (liver, gill, kidney and brain) were taken in ice-cold containers. The tissue homogenates were prepared in appropriate buffers for each estimation. The concentration of the lipid peroxidation product malondialdehyde ${ }^{2}$ (MDA), the non-enzymatic antioxidant reduced glutathione ${ }^{3}$ (GSH), and activities of the enzymes catalase ${ }^{4}(\mathrm{CAT})$, superoxide 


\section{International Journal of Science and Research (IJSR) \\ ISSN (Online): 2319-7064}

Index Copernicus Value (2013): 6.14 | Impact Factor (2015): 6.391

dismutase $^{5}$ (SOD), glutathione peroxidase $^{7} \quad(\mathrm{GPx})$, glutathione-S-transferase ${ }^{6}$ (GST) were determined spectrophotometrically using standard procedures. Analysis of important physico-chemical characteristics of aquarium water collected initially (before passing $\mathrm{H}_{2} \mathrm{~S}$ ) and during the experimental period was carried out according to standard procedures described in $\mathrm{APHA}^{8}$. All the biochemicals used for the estimations were purchased from Loba Chemie Pvt., India. All other chemicals used in this study were of analytical grade.

\section{Statistical Analysis}

All the data are expressed as mean \pm SD. Statistical significance of the data was determined by one way ANOVA (Duncan's test) using SPSS software. Two significant levels $(0.05$, and 0.001$)$ were selected for the analysis.

\section{Results}

\section{1) Changes in Physico-chemical characteristics of Water:}

The physico-chemical characteristics of aquarium water with control group and test groups are given in Table 1(a), 1(b) and $1(\mathrm{c})$. The fishes in test groups $\mathrm{T}_{1}$ and $\mathrm{T}_{2}$ exhibited erratic movements during the experiment. The temperature of water in control group is $26.5 \pm 0.58^{\circ} \mathrm{C}$ while that of the test group varies from $25.75 \pm 0.05{ }^{\circ} \mathrm{C}$ to $28 \pm 2.03{ }^{\circ} \mathrm{C}$. The hydrogen sulphide concentration in control group is zero while in $\mathrm{T}_{1}$ group the hydrogen sulphide content in water after two minute passage is $4.9 \pm 0.02 \mathrm{mg} / \mathrm{L}$ and then after the $96 \mathrm{hrs}$ experimental periods, it reaches to $2 \pm 0.02 \mathrm{mg} / \mathrm{L}$. In $\mathrm{T}_{2}$ group the $\mathrm{H}_{2} \mathrm{~S}$ content in water after five minutes passage is $6.6 \pm 0.07 \mathrm{mg} / \mathrm{L}$, and it decreases to $2.0 \pm 0.09 \mathrm{mg} / \mathrm{L}$ after 96 hrs. The DO content in control group varies from $6.22 \pm 0.09$ $\mathrm{mg} / \mathrm{L}$ to $7.39 \pm 0.03 \mathrm{mg} / \mathrm{L}$, while that of $\mathrm{T}_{1}$ group varies from $2.2 \pm 0.01 \mathrm{mg} / \mathrm{L}$ to $4.2 \pm 0.05 \mathrm{mg} / \mathrm{L}$ and $\mathrm{T}_{2}$ group varies from $1.0 \pm 0.06 \mathrm{mg} / \mathrm{L}$ to $3.8 \pm 1.40 \mathrm{mg} / \mathrm{L}$. The $\mathrm{pH}$ of the control group varies from $6.66 \pm 0.17$ to $6.82 \pm 0.05$. The $\mathrm{pH}$ of $\mathrm{T}_{1}$ group varies from $6.0 \pm 0.12$ to $6.4 \pm 0.09$ while that of $\mathrm{T}_{2}$ varies from $6.0 \pm 0.28$ to $6.3 \pm 0.41$.

2) Lipid peroxidative changes in Fishes exposed to $\mathrm{H}_{2} \mathrm{~S}$ : The changes in the concentration of malondialdehyde (MDA) and activities of enzymatic antioxidants in the fishes exposed to hydrogen sulphide with respect to the control group are given in Table 2 to 7.

Changes in lipid peroxidation (LP) leads to destruction of membrane lipids and production of lipid peroxides and their byproducts such as aldehydes. The MDA content in liver of the fishes in $\mathrm{T}_{1}$ group (48 hrs) was $232 \pm 0.16 \mu$ moles $/ 100 \mathrm{~g}$ wet tissue and in $\mathrm{T}_{2}$ group (48 hrs), it was $239 \pm 0.90 \mu$ moles/100 $\mathrm{g}$ wet tissue compared to that of the control fishes. In gills, MDA content was recorded as $143 \pm 3.78 \mu$ moles/100 g wet tissue in $\mathrm{T}_{1}$ group (48hr) and $145 \pm 5.77 \mu$ moles/100 $\mathrm{g}$ wet tissue in $\mathrm{T}_{2}$ group, compared to that of the control group $(122 \pm 1.70 \mu$ moles/100 $\mathrm{g}$ wet tissue). The kidney MDA content showed a significant increase to $103 \pm 3.0 \mu$ moles $/ 100 \mathrm{~g}$ wet tissue in $\mathrm{T}_{1}$ group ( $48 \mathrm{hrs}$ ) and to $122 \pm 0.02 \mu$ moles $/ 100 \mathrm{~g}$ wet tissue in $\mathrm{T}_{2}$ group (48 hrs) compared to that of the control group ie. $84 \pm 1.29 \mu$ moles/100 $\mathrm{g}$ wet tissue. In the brain tissue of $\mathrm{T}_{1}$ group $(48$ hrs) the MDA content was estimated as $51 \pm 0.26 \mu$ moles $/ 100 \mathrm{~g}$ wet tissue and in $\mathrm{T}_{2}$ group (48 hrs) it was $53 \pm 3.41 \mu$ moles $/ 100 \mathrm{~g}$ wet tissue, which were significantly higher $(\mathrm{P}<0.05)$ than their respective healthy controls. After 48 hours the MDA values in different tissues remain constant upto the end of the experimental period ( $96 \mathrm{hrs}$ ) and it was also observed that the $\mathrm{H}_{2} \mathrm{~S}$ concentration in aquarium water also decreased with time.

In the present investigation liver, gill and brain showed time and dose dependent decline in GSH level. There was initial elevation in GSH level, but in the low and medium lethal concentrations of $\mathrm{H}_{2} \mathrm{~S}$ affected fishes there is a decrease in GSH level towards the end of the experiment. It varies from $1250 \pm 6.27 \mathrm{~nm} / 100$ fresh wt (C) to $1273 \pm 3.82 \mathrm{~nm} / 100$ fresh wt (24hr) $1320 \pm 2.38 \mathrm{~nm} / 100$ fresh wt $(48 \mathrm{hr})$ in liver, $1058 \pm 1.63 \mathrm{~nm} / 100$ fresh wt (C) to $1226 \pm 1.29 \mathrm{~nm} / 100$ fresh wt (72hr) and $1251 \pm 1.89(72 \mathrm{hr})$ in gills, $1288 \pm 0.95 \mathrm{~nm} / 100$ fresh wt (C) to $1554 \pm 1.25 \mathrm{~nm} / 100$ fresh wt (C) to $1574 \pm 2.23 \mathrm{~nm} / 100$ fresh wt (96hr)in kidney, and in brain it varies from $619 \pm 1.29 \mathrm{~nm} / 100$ fresh wt to $995 \pm 6.07 \mathrm{~nm} / 100$ fresh wt (12hr) to $1124 \pm 1.71 \mathrm{~nm} / 100$ fresh wt (48hr) of T1 and $\mathrm{T} 2$ groups.

The activity of superoxide dismutase (SOD) in the liver of Oreochromis mossambicus recorded $6.28 \pm 0.50$ units in control group, while the activity was $9.31 \pm 0.07$ units $(12 \mathrm{hr})$ and $10.67 \pm 0.42$ units $(12 \mathrm{hr})$ in $\mathrm{T}_{1}$ and $\mathrm{T}_{2}$ groups respectively. In the gills, SOD activity varies between $1.57 \pm 0.21$ units $(C)$ to $3.14 \pm 0.34$ units $(12 \mathrm{hr})$ and $3.74 \pm 0.55$ units (12hr) in $\mathrm{T}_{1}$ and $\mathrm{T}_{2}$ groups respectively. In the kidney and brain of $T_{1}$ and $T_{2}$ group the SOD activity increases on exposure to $\mathrm{H}_{2} \mathrm{~S}$ upto $24 \mathrm{hrs}$ and then it decreases. The increase in SOD activity in all the tissue samples of test groups were significantly high $(\mathrm{P}<0.05)$ compared to that of the healthy control fishes.

The liver catalase activity increases in the hydrogen sulphide treated test groups $\mathrm{T}_{1}$ and $\mathrm{T}_{2}$ and recorded as $11.50 \pm 0.926$ units $(12 \mathrm{hr})$ and $12.27 \pm 0.24$ units $(12 \mathrm{hr})$ respectively compared to that $10.18 \pm 0.09$ units of the control group. Similar increase was observed in other tissues of the test groups studied. The activity of CAT in the tissues of test group fishes further increased up to $24 \mathrm{hrs}$ and there is a slight decrease in CAT activity in liver, gills, kidney and brain after $72 \mathrm{hrs}$ upto $96 \mathrm{hrs}$.

Glutathione peroxidases (GPx) are regarded as important component of the cellular system defense against oxidative stress. In the present study, a sharp, duration dependent decrease in GPx activity level was recorded in all tissues. The GPx activity in liver ranges from 5.84 \pm 0.01 units $(C)$ to $6.93 \pm 0.23$ units $(48 \mathrm{hr})$ and $7.99 \pm 0.842$ units $(12 \mathrm{hr})$ and in gills $2.96 \pm 0.01$ units (C) to $3.52 \pm 0.52$ units $(12 \mathrm{hr})$ and $3.69 \pm 0.44$ units $(12 \mathrm{hr}), 0.58 \pm 0.01$ units $(\mathrm{C})$ to $1.08 \pm 0.10$ units (12hr) and $1.09 \pm 0.01$ units $(12 \mathrm{hr})$ in kidney, and $0.107 \pm 0.027$ units (C) to $0.217 \pm 0.029$ units $(12 \mathrm{hr})$ and $0.29 \pm 0.04$ units (12hr) in brain of $\mathrm{T}_{1}$ and $\mathrm{T}_{2}$ groups.

Glutathione S-Transferase (GST) is an enzyme involved in the detoxification and conjugation of xenobiotics and in protecting against peroxidative damage. In this study GST showed a duration dependent elevation in GST activity was 


\section{International Journal of Science and Research (IJSR) \\ ISSN (Online): 2319-7064 \\ Index Copernicus Value (2013): 6.14 | Impact Factor (2015): 6.391}

noted. The GST activity in the liver of fish samples was recorded as $3.05 \pm 0.02$ units (C) to $3.77 \pm 0.37$ units (12hr) and $3.98 \pm 0.60$ units $(12 \mathrm{hr}$ ) and in gills from $0.615 \pm 0.02$ units (C) to $0.86 \pm 0.08$ units $(12 \mathrm{hr})$ and $0.942 \pm 0.05$ units (12hr), from $2.11 \pm 0.01$ units (C) to $3.12 \pm 0.75$ units (24hr) and 3.36 \pm 0.18 units (24hr) in kidney, and from $0.167 \pm 0.04$ units $(\mathrm{C})$ to $0.26 \pm 0.03$ units $(24 \mathrm{hr})$ to $0.37 \pm 0.02$ units $(12 \mathrm{hr})$ in the brain of $\mathrm{T}_{1}$ and $\mathrm{T}_{2}$ groups respectively. On exposure to the highest concentration of $\mathrm{H}_{2} \mathrm{~S}$, all the four tissues of the fishes studied in both groups exhibited inhibition in GST activity.

\section{Discussion}

The physico-chemical characteristics of the hydrogen sulphide exposed aquarium water shows that there was a considerable decline in oxygen level and $\mathrm{pH}$, which leads to chronic oxidative stress in fishes. In water, the $\mathrm{H}_{2} \mathrm{~S}$ dissociates forming monohydrogensulfide (HS-) and sulfide $\left(\mathrm{S}^{2}-\right)$ ions. The relative concentrations of these species are a function of the $\mathrm{pH}$ of the water. In aerated water, hydrogen sulfide is readily oxidized to sulfates and biologically oxidized to elemental sulphur. The conversion of $\mathrm{H}_{2} \mathrm{~S}$ into sulphate and sulphides cause extra pressure to the fishes ${ }^{9}$.

Hydrogen sulphide is a potent inhibitor of aerobic respiration. $\mathrm{H}_{2} \mathrm{~S}$ exposure causes oxidative stress in fishes and results in lipid peroxidation. Lipid peroxidation leads to sdestruction of membrane lipids and production of lipid peroxides and their by-products such as aldehydes. MDA is formed from the breakdown of polyunsaturated fatty acids (PUFA) and it serves as a convenient index for determining the extent of lipid peroxidation ${ }^{10}$. It can be considered as a biomarker of effect representing the state of membrane lipid peroxidation. In the present investigation, liver, kidney and gill of the fishes subjected to different concentrations of hydrogen sulphide exhibited elevated MDA level which was both time and dose dependent. Studies also showed similar increase in MDA content in the muscle and gill tissues of Oreochromis niloticus exposed to high concentrations of etoxazole in long-term durations ${ }^{11}$. In the present experimental study, kidney of test fishes showed the highest MDA content compared to that of control samples. This might be due to the elevated oxidation of molecular oxygen to produce superoxide radicals indicating the importance of kidney in the detoxification process. This reaction could also be the source of $\mathrm{H}_{2} \mathrm{O}_{2}$, which caused the production of MDA by initiating the peroxidation of unsaturated fatty acids in the membrane. The efforts of the endogenous antioxidant enzymes to remove the continuously generated free radicals initially increase due to an induction but later enzyme depletion results, resulting in oxidative cell damage. In the case of environmental exposure of fishes in surface waters to hydrogen sulphide by different anthropogenic activities occasionally, the generation of reactive free radicals overwhelms the function of antioxidant defence mechanisms, lipid peroxidation of the cell membrane occurs. Therefore this causes disturbances in cell integrity and might lead to cell damage/death ${ }^{12}$.

Glutathione (GSH) is a sulfhydyl (-SH) antioxidant, antitoxin, and enzyme co- factor. It is involved in many process including protein and DNA synthesis, xenobiotics conjugation and antioxidant protection. Although there was a significantly high $(\mathrm{P}<0.05)$ initial elevation in $\mathrm{GSH}$ level and the activity of this enzyme decreased significantly in liver, gill, kidney and brain $(\mathrm{P}<0.001)$. Increased GSH level could be an adaptive mechanism to slight oxidative stress, but decreased GSH level could be due to loss of adaptive mechanisms and the oxidation of GSH to GSSG (oxidised glutathione). When fish tissues are in contact with the toxicant these were removed by conjugation with GSH directly or by means of GSTs which decreased GSH levels. In addition, the oxidative damage caused by metabolites of the toxicant could be mediated by uncoupling of mitochondrial oxidative phosphorylation ${ }^{13}$.

SOD is one of the key enzymes that provide the first line defense against the pro-oxidants catalyses the transformation of superoxide radicals to $\mathrm{H}_{2} \mathrm{O}_{2}$ and $\mathrm{O}_{2}{ }^{14}$. Toxic stress is known to alter the activity of SOD in the vital tissues of fish. In the present study the sublethal and medium lethal concentrations of $\mathrm{H}_{2} \mathrm{~S}$ exposure to fishes shows an initial elevation in SOD activity upto 24 hrs followed by reduction towards the end of the experiment. The initial increase in SOD activity indicated the generation of superoxide radical anion, and the inhibition at the end might be due to the higher amount of oxyradical formation than that could be neutralized by the enzyme. It has also been reported in some cases that the superoxide radical by itself or after its transformation to $\mathrm{H}_{2} \mathrm{O}_{2}$ caused a strong oxidation of the cysteine in the enzyme and decrease in the SOD activity ${ }^{15}$.

Catalase belongs to the cellular antioxidant system that counteracts the toxicity of ROS. They are the hemecotaining enzymes that facilitate the removal of hydrogen peroxide $\left(\mathrm{H}_{2} \mathrm{O}_{2}\right)$, which is metabolised to molecular oxygen $\left(\mathrm{O}_{2}\right)$ and water. In the present investigation CAT activity was significantly $(\mathrm{P}<0.05)$ increased at the initial phase. A pro-oxidant condition elicited by the presence of toxicant could be triggering an increase in the activity of this antioxidant enzyme at the initial stages of exposure as an adaptive response ${ }^{16}$. There was a significant decrease $(\mathrm{P}<0.05)$ in activity of CAT was observed in $96 \mathrm{hr}$ experiment. The low levels of CAT could be attributed high production of superoxide anion radical ${ }^{17}$.

Peroxidases are enzymes that reduce a variety of peroxides to their corresponding alcohols. Glutathione peroxide is considered to play an especially important role in protecting membranes from damage due to lipidperoxidation. This observation led to the view that the major detoxification function of GPx is the termination of radical chain propagation by quick reduction to yield further radicals ${ }^{18}$. Glutathione peroxidases are regarded as important components of the cellular system of defence against oxidative stress resulting from the metabolism of xenobiotics $^{19}$. In the present experiment, a significantly $(\mathrm{P}<0.001)$ sharp duration dependant decrease in GPx activity level was recorded in highest duration of exposure. The low activity of GPx in different tissues of exposed fish demonstrated the incapability of these organs in neutralising the impact of peroxides ${ }^{20}$. The reduction of GPx activity in various tissues in the $\mathrm{H}_{2} \mathrm{~S}$ exposed fish might be attributed to the longer influence of various organic and inorganic redox active contaminants ${ }^{21}$. The decreased level of GPx in the 


\section{International Journal of Science and Research (IJSR) \\ ISSN (Online): 2319-7064}

Index Copernicus Value (2013): 6.14 | Impact Factor (2015): 6.391

$\mathrm{H}_{2} \mathrm{~S}$ intoxicated fish might weaken the antioxidant defence system of the fish which would eventually affect their survival.

Glutathione-S-Transferase (GST), an enzyme involved in the detoxification and conjugation of xenobiotics and in protecting against peroxidative damage, is ubiquitous in the cytosol and microsomes of eukaryotes. Significant $(\mathrm{P}<0.05)$ duration dependent elevation in GST activity was noted in the tissues of Oreochromis mossambicus intoxicated with the low and intermediate sublethal concentrations of $\mathrm{H}_{2} \mathrm{~S}$ in the present experiment. GST mediated conjugation might be an important mechanism for detoxifying peroxidised lipid breakdown products, which have a number of adverse biological effects when present in higher amounts. Induced GST activity indicated the role of this enzyme in protection against the toxicity of xenobiotics ${ }^{22}$. At the highest sublethal concentration, all the three tissues of the fish exhibited inhibition in GST activity. These results are in relation with the studies ${ }^{23}$ reported in the Egyptian catfish Clarias lazera subjected to dimethoate exposure, and the study showed strong inhibition of GST in the exposed fish. The reduction in GST activity level noted at the highest exposure time of $\mathrm{H}_{2} \mathrm{~S}$ indicated the impaired detoxification mechanism of the fish under long-term exposure.

\section{Conclusion}

The observations from the present study showed that hydrogen sulphide at sublethal and medium lethal concentrations altered the rate of lipid peroxidation and activities of antioxidant systems in various organs of the test fish. There is a time and dose dependent elevation in MDA level, one of the end products of lipid peroxidation occurred during oxidative stress in $\mathrm{H}_{2} \mathrm{~S}$ exposed fishes. Also, there is an initial elevation in the concentrations of antioxidants SOD, CAT and GSH in different tissues during $\mathrm{H}_{2} \mathrm{~S}$ exposure followed by gradual reduction in the activities of enzymes. A sharp duration dependant decrease in GPx activity and, the dose and duration dependent elevation in GST activity shows the hydrogen sulphide exposure causes stress in aquatic organisms which results in changes in the physiological conditions of the organisms. This study on lipid peroxidative changes in Oreochromis mossambicus in hydrogen sulphide contaminated water shows that biochemical and antioxidant enzyme activities plays an important role in the quality assessment of the $\mathrm{H}_{2} \mathrm{~S}$ polluted aquatic medium in which they survive and also for monitoring the fish health in coir retting areas of estuaries.

\section{Acknowledgements}

The authors thank the Professor and Head of the Department of Environmental Sciences, University of Kerala for the facilities provided for this study. Also gratefully acknowledge Dr. Mohanan, Reader, Department of Chemistry for his valuable suggestions for doing the experimental study.

\section{References}

[1] Colby P. J. and Smith L. L., Survival of wall eye egg and fry on paper fibre sludge deposits in Rainy Rivers, Minnesota, Trans. Amer. Fish. Doc, 96 (1967) 296.

[2] Niehaus W. G. and Samuelsson B., Formation of Malondialdehyde from phospholipid, arachidonate during microsomal lipid peroxidation. Eur J Biochem, 6 (1968) 130.

[3] Pattersson. J. W. and Lazarow A., Determination of Glutathione, Methods Biochem, Anal, 2 (1955) 278.

[4] Maehly A. C. and Chance B., The assay of catalases and peroxidases. In: Glick D (ed) Methods of biochemical analysis Vol. I, Interscience press, New York, (1954) 424.

[5] Kakkar P., Das B. and Viswanathan P. N., A modified spectrophotometric assay of superoxide dismutase. Ind J Biochem Biophys, 21 (1984) 132.

[6] Paglia D. E. and Valentine W. N., Studies on the quantitative and qualitative characterisation of erythrocyte glutathione peroxidase. J Clin Lab Med, 70 (1967) 169.

[7] Habig W. H., Pabst M. J. and Jokoby W. B., Glutathione S-transferase, the first enzymatic step in mercapturic acid formation. J Biol Chem, 249 (1974) 7139.

[8] APHA Standard Methods for the Examination of Water and Waste-Water, 20 ${ }^{\text {th }}$ edition. In: Clesceri LS, Greenberg AE, Eaton A D, (eds) American Public Health Association, Washington, D C (1998).

[9] WHO Guidelines for drinking-water quality, 2nd ed. Vol. 2. Health criteria and other supporting information. World Health Organization. Geneva, (1996)

[10] Jamil K., Bioindicators and Biomarkers of Environmental pollution and Risk Assessment. Science Publisher Inc. Enfield, USA, (2001) 146.

[11] Uner N., Oruc E. and Sevgiler Y., Oxidative stressrelated and ATPases effects of etoxazole in different tissues of Oreochromis niloticus. Environ Toxicol Pharmacol, 20 (2005) 106.

[12] Fang S. C., Thiocarbamates. In: Kearney P C, Kaufman D D, (eds) Herbicides- chemistry, degradation and mode of action. Marcel Dekker, New York, (1975) 348.

[13] Kalra J., Mantha S. V. and Prasad K., Oxygen free radicals: Key factors in clinical diseases. Lab Medical International,(1994) 9.

[14]Lauterburg B. H., Smith C. V., Hughes H. and Mitchell J. R., Determinants of hepatic glutathione turnover: toxicological significance. In: Lamble J. W., (Ed) Drug metabolism and distribution. Elsevier Biomedical Press. Amsterdam, (1983) 180.

[15] Kappus H., Lipid peroxidation: mechanisms,analysis, enzymology and biological relevance. In: Sies H (ed) Oxidative stress. Academic press, London, (1985) 310.

[16] Dimitrova M. S., Tishinova V. and Velcheva V., Combined effect of zinc and lead on the hepatic superoxide dismutase-catalase system in carp (Cyprinus carpio) Comp Biochem Physiol, 108 (1994) 46.

[17] Alves S. R. C., Severino P. C. and Ibbotson D. P., Effect of furadan in the brown mussel Perna perna and in the mangrove oyster Crassostrea rhizophorae. Mar Environ Res, 54 (2002) 5. 


\section{International Journal of Science and Research (IJSR) \\ ISSN (Online): 2319-7064 \\ Index Copernicus Value (2013): 6.14 | Impact Factor (2015): 6.391}

[18] Kono Y. and Fridovich I., Superoxide radical inhibits catalase. J Biol Chem, (1982) 5751.

[19] Thomas J. P., Maiorino M., Ursini F. and Girotti A. W., Protective action of phospholipid hydroperoxide glutathione peroxidase against membrane damaging lipid peroxidation. J Biol Chem, 265 (1990) 461.

[20]Fatima M., Ahmad I., Sayeed I., Athar M. and Raisuddin S., Pollutant induced over activation of phagocytes is concomitantly associated with peroxidative damage in fish tissues. Aquat Toxicol , 49 (2000) 250.
[21] Santos M. A., Pacheco M. and Ahmad I., Antioxidant responses to in situ bleached craft pulpmill effluent outlet exposure to Anguilla anguilla. Environ Int,(2004) 301.

[22] Leaver M. J. and George S. G., A piscidine glutathione S-transferase which efficiently conjugates the end products of lipid peroxidation. Mar Environ Res, 46 (1998) 74.

[23] Hamed R. R., Elawa S..E. and Farid N. M., Evaluation of detoxification of enzyme levels in Egyptian cat fish, Clarias lazera, exposed to dimethoate. Bull Environ Contam Toxicol, 63 (1999) 796.

Table 1(a): Physico-chemical characteristics of aquarium water with Control group fishes

\begin{tabular}{|c|c|c|c|c|c|c|}
\hline Parameters & Initial & $12 \mathrm{hr}$ & $24 \mathrm{hr}$ & $48 \mathrm{hr}$ & $72 \mathrm{hr}$ & $96 \mathrm{hr}$ \\
\hline Temperature $\left({ }^{0} \mathrm{C}\right)$ & $25.25 \pm 0.96$ & $26.25 \pm 0.5$ & $26.5 \pm 0.58$ & $26 \pm 1.63$ & $25.75 \pm 0.96$ & $25.5 \pm 1.23$ \\
\hline $\mathrm{pH}$ & $6.75 \pm 0.06$ & $6.67 \pm 0.12$ & $6.67 \pm 0.12$ & $6.7 \pm 0.08$ & $6.82 \pm 0.05$ & $6.66 \pm 0.17$ \\
\hline $\mathrm{DO}(\mathrm{mg} / \mathrm{L})$ & $7.22 \pm 0.09$ & $7.39 \pm 0.03$ & $7.27 \pm 0.04$ & $7.25 \pm 0.04$ & $7.29 \pm 0.05$ & $7.03 \pm 0.16$ \\
\hline $\mathrm{H}_{2} \mathrm{~S}(\mathrm{mg} / \mathrm{L})$ & $0.0 \pm 0.00$ & $0.0 \pm 0.00$ & $0.0 \pm 0.00$ & $0.0 \pm 0.00$ & $0.0 \pm 0.00$ & $0.0 \pm 0.00$ \\
\hline Sulphate $(\mathrm{mg} / \mathrm{L})$ & $1.23 \pm 0.02$ & $1.25 \pm 0.02$ & $1.25 \pm 0.02$ & $1.25 \pm 0.04$ & $1.23 \pm 0.00$ & $1.21 \pm 0.05$ \\
\hline
\end{tabular}

Table 1(b): Physico-chemical characteristics of aquarium water with $\mathrm{T}_{1}$ group fishes

\begin{tabular}{|c|c|c|c|c|c|c|}
\hline Parameters & $2^{\prime}$ & $12 \mathrm{hr}$ & $24 \mathrm{hr}$ & $48 \mathrm{hr}$ & $72 \mathrm{hr}$ & $96 \mathrm{hr}$ \\
\hline Temperature $\left({ }^{0} \mathrm{C}\right)$ & $26.5 \pm 0.56$ & $27 \pm 0.81$ & $27 \pm 0.82$ & $27 \pm 0.82$ & $25.75 \pm 0.96$ & $25.75 \pm 0.05$ \\
\hline $\mathrm{pH}$ & $6.0 \pm 0.12$ & $6.2 \pm 0.05$ & $6.1 \pm 0.02$ & $6.1 \pm 0.01$ & $6.4 \pm 0.09$ & $6.3 \pm 0.09$ \\
\hline $\mathrm{DO}(\mathrm{mg} / \mathrm{L})$ & $2.2 \pm 0.01$ & $2.4 \pm 0.05$ & $2.8 \pm 0.08$ & $3.2 \pm 0.12$ & $3.6 \pm 012$ & $4.2 \pm 0.05$ \\
\hline $\mathrm{H}_{2} \mathrm{~S}(\mathrm{mg} / \mathrm{L})$ & $4.9 \pm 0.02$ & $4.02 \pm 0 / 04$ & $3.6 \pm 0.12$ & $2.8 \pm 1.22$ & $2.2 \pm 0.08$ & $2.0 \pm 0.02$ \\
\hline Sulphate $(\mathrm{mg} / \mathrm{L})$ & $1.53 \pm 0.81$ & $1.53 \pm 1.12$ & $1.67 \pm 0.05$ & $1.70 \pm 0.02$ & $1.76 \pm 0.52$ & $1.78 \pm 1.45$ \\
\hline
\end{tabular}

Table 1(c): Physico-chemical characteristics of aquarium water with $\mathrm{T}_{2}$ group fishes

\begin{tabular}{|c|c|c|c|c|c|c|}
\hline Parameters & 5 & $12 \mathrm{hr}$ & $24 \mathrm{hr}$ & $48 \mathrm{hr}$ & $72 \mathrm{hr}$ & $96 \mathrm{hr}$ \\
\hline Temperature $\left({ }^{0} \mathrm{C}\right)$ & $28 \pm 2.03$ & $28 \pm 0.07$ & $27 \pm 0.06$ & $27 \pm 0.22$ & $27 \pm 0.15$ & $27 \pm 0.08$ \\
\hline $\mathrm{pH}$ & $6.0 \pm 0.28$ & $6.1 \pm 0.44$ & $6.1 \pm 1.45$ & $6.0 \pm 1.03$ & $6.2 \pm 0.33$ & $6.3 \pm 0.41$ \\
\hline $\mathrm{DO}(\mathrm{mg} / \mathrm{L})$ & $1.0 \pm 0.06$ & $2.4 \pm 1.03$ & $2.8 \pm 1.21$ & $3.2 \pm 1.32$ & $3.6 \pm 0.03$ & $3.8 \pm 1.40$ \\
\hline $\mathrm{H}_{2} \mathrm{~S}(\mathrm{mg} / \mathrm{L})$ & $6.6 \pm 0.07$ & $5.8 \pm 0.32$ & $4.2 \pm 0.44$ & $3.4 \pm 0.04$ & $2.6 \pm 0.18$ & $2.0 \pm 0.09$ \\
\hline Sulphate $(\mathrm{mg} / \mathrm{L})$ & $1.88 \pm 0.05$ & $1.89 \pm 1.22$ & $1.91 \pm 0.06$ & $1.96 \pm 0.01$ & $1.99 \pm 0.07$ & $1.99 \pm 0.08$ \\
\hline
\end{tabular}

Table 2 : Changes in Malondialdehyde content in Fish tissues

(Values are Mean \pm S.D, $\mathrm{n}=6$ )

\begin{tabular}{|c|c|c|c|c|c|c|c|c|c|c|c|c|}
\hline \multirow{3}{*}{$\begin{array}{c}\text { Time interval } \\
\text { (Hours) }\end{array}$} & \multicolumn{12}{|c|}{ Malondialdehyde (micromoles/100 g wet tissue) } \\
\hline & & Liver & & & Gill & & & Kidney & & & Brain & \\
\hline & $\mathrm{T} 1$ & $\mathrm{~T} 2$ & Control & $\mathrm{T} 1$ & $\mathrm{~T} 2$ & Control & $\mathrm{T} 1$ & $\mathrm{~T} 2$ & Control & $\mathrm{T} 2$ & $\mathrm{~T} 2$ & Control \\
\hline Initial & $219 \pm 0.89 *$ & $224 \pm 6.84 *$ & $193 \pm 0.09$ & $132 \pm 2.82 *$ & $132 \pm 3.00 *$ & $122 \pm 1.70$ & $94 \pm 5.50 *$ & $99 \pm 7.27 *$ & $84 \pm 2.08$ & $48 \pm 0.11 *$ & $42 \pm 2.51 *$ & $36 \pm 1.63$ \\
\hline 12 & $223 \pm 0.15^{*}$ & $230 \pm 7.11^{*}$ & $193 \pm 0.12$ & $140 \pm 4.39 *$ & $141 \pm 5.00^{*}$ & $123 \pm 1.03$ & $98 \pm 4.72 *$ & $108 \pm 9.88^{*}$ & $84 \pm 1.29$ & $51 \pm 0.26^{*}$ & $51 \pm 3.82 *$ & $35 \pm 1.71$ \\
\hline 24 & $231 \pm 0.04 *$ & $238 \pm 7.27 *$ & $193 \pm .0 .00$ & $142 \pm 4.03 *$ & $145 \pm 5.77 *$ & $123 \pm 1.26$ & $103 \pm 3.00^{*}$ & $113 \pm 8.99 *$ & $84 \pm 2.16$ & $51 \pm 0.19 *$ & $53 \pm 3.41 *$ & $36 \pm 1.70$ \\
\hline 48 & $232 \pm 0.16^{*}$ & $239 \pm 0.14^{*}$ & $193 \pm 0.56$ & $143 \pm 1.73^{*}$ & $144 \pm 0.01 *$ & $124 \pm 0.95$ & $101 \pm 2.50^{*}$ & $122 \pm 0.01 *$ & $84 \pm 1.73$ & $49 \pm 1.91 *$ & $51 \pm 3.59 *$ & $37 \pm 1.15$ \\
\hline 72 & $232 \pm 0.06^{*}$ & $239 \pm 0.12 *$ & $193 \pm 0.96$ & $143 \pm 3.78^{*}$ & $143 \pm 0.02 *$ & $124 \pm 0.96$ & $101 \pm 0.08^{*}$ & $122 \pm 0.01 *$ & $85 \pm 1.00$ & $49 \pm 0.23 *$ & $51 \pm 0.02$ & $35 \pm 1.25$ \\
\hline 96 & $232 \pm 0.07 *$ & $239 \pm 1.90^{*}$ & $193 \pm 0.48$ & $143 \pm 0.04 *$ & $144 \pm 0.10 *$ & $124 \pm 0.96$ & $101 \pm 0.02 *$ & $122 \pm 0.02 *$ & $84 \pm 2.06$ & $49 \pm 0.02 *$ & $51 \pm 0.01$ & $35 \pm 1.29$ \\
\hline
\end{tabular}

Table 3: Changes in Glutathione (GSH) Content in Fish tissues

(Values are Mean \pm S.D, $n=6$ )

\begin{tabular}{|c|c|c|c|c|c|c|c|c|c|c|c|c|}
\hline \multirow{3}{*}{$\begin{array}{l}\text { Time } \\
\text { interval } \\
\text { (Hours) }\end{array}$} & \multicolumn{12}{|c|}{ Glutathione (nanomoles /100 fresh w) } \\
\hline & & Liver & & & Gill & & & Kidney & & & Brain & \\
\hline & $\mathrm{T} 1$ & $\mathrm{~T} 2$ & Control & $\mathrm{T} 1$ & $\mathrm{~T} 2$ & Control & $\mathrm{T} 1$ & $\mathrm{~T} 2$ & Control & $\mathrm{T} 2$ & $\mathrm{~T} 2$ & Control \\
\hline 0 & $1266 \pm 8.06^{*}$ & $1272 \pm 3.56^{*}$ & $1250 \pm 6.27$ & $1122 \pm 0.29 *$ & $1125 \pm 4.43^{*}$ & $1058 \pm 1.63$ & $1326 \pm 1.32 *$ & $1375 \pm 2.94 *$ & $1288 \pm 0.95$ & $948 \pm 0.95 *$ & $1104 \pm 2.64 *$ & $620 \pm 0.58$ \\
\hline 12 & $1272 \pm 7.11 * *$ & $1286 \pm 1.70^{*}$ & $1250 \pm 7.04$ & $1221 \pm 4.96^{*}$ & $1222 \pm 0.95^{*}$ & $1058 \pm 1.0$ & $1382 \pm 2.64 *$ & $1425 \pm 2.5^{*}$ & $1290 \pm 0.95$ & $995 \pm 6.07 *$ & $1105 \pm 2.22 *$ & $622 \pm 1.70$ \\
\hline 24 & $1273 \pm 3.82 *$ & $1304 \pm 3.65 *$ & $1251 \pm 5.48$ & $1222 \pm 129$ & $1246 \pm 2.70 *$ & $1059 \pm 1.29$ & $1363 \pm 3.5 *$ & $1456 \pm 2.87 * *$ & $1292 \pm 1.5$ & $988 \pm 5.91 *$ & $1124 \pm 1.71 *$ & $620 \pm 0.50$ \\
\hline 48 & $1262 \pm 4.90$ & $1320 \pm 2.38$ & $1250 \pm 6.78$ & $1225 \pm 2.58 *$ & $1245 \pm 1.63$ & $1060 \pm 2.16$ & $1459 \pm 1.70$ & $1535 \pm 1.91 * *$ & $1291 \pm 1.29$ & $865 \pm 6.45^{*}$ & $983 \pm 1.26^{*}$ & $619 \pm 1.29$ \\
\hline 72 & $1260 \pm 0.17$ & $1299 \pm 0.37$ & $1251 \pm 5.61$ & $1226 \pm 1.29$ & $1246 \pm 1.82 *$ & $1060 \pm 3.0$ & $1553 \pm 2.5$ & $1574 \pm 1.71$ & $1292 \pm 1.5$ & $854 \pm 1.73 *$ & $82 \pm 2.38 * *$ & $620 \pm 0.57$ \\
\hline 96 & $1260 \pm 0.17$ & $1298 \pm 0.06$ & $1251 \pm 2.06$ & $1225 \pm 1.23$ & $1251 \pm 1.89$ & $1061 \pm 2.38$ & $1554 \pm 1.25$ & $1574 \pm 2.23$ & $1291 \pm 3.10$ & $851 \pm 1.71 *$ & $981 \pm 0.82 *$ & $620 \pm 1.82$ \\
\hline
\end{tabular}

\section{Volume 5 Issue 6, June 2016} www.ijsr.net

Licensed Under Creative Commons Attribution CC BY 


\section{International Journal of Science and Research (IJSR) \\ ISSN (Online): 2319-7064}

Index Copernicus Value (2013): 6.14 | Impact Factor (2015): 6.391

Table 4: Changes in Superoxide dismutase activity in fish tissues

(Values are Mean \pm S.D, $n=6$ )

\begin{tabular}{|c|c|c|c|c|c|c|c|c|c|c|c|c|}
\hline \multirow{3}{*}{$\begin{array}{l}\text { Time } \\
\text { interval } \\
\text { (Hours) }\end{array}$} & \multicolumn{11}{|c|}{ Superoxide dismutase activity (Units/mg protein) } & \\
\hline & & Liver & & & Gill & & & Kidney & & & Brain & \\
\hline & $\mathrm{T} 1$ & $\mathrm{~T} 2$ & Control & $\mathrm{T} 1$ & $\mathrm{~T} 2$ & Control & $\mathrm{T} 1$ & $\mathrm{~T} 2$ & Control & $\mathrm{T} 2$ & $\mathrm{~T} 2$ & Control \\
\hline 0 & $9.19 \pm 0.12 *$ & $10.21 \pm 0.13 *$ & $6.86 \pm 0.12$ & $2.75 \pm 0.39 *$ & $2.74 \pm 0.50 *$ & $1.74 \pm 0.45$ & $9.27 \pm 0.11 * *$ & $9.93 \pm 0.02 *$ & $5.58 \pm 0.57$ & $0.72 \pm 0.05 *$ & $0.84 \pm 0.13 *$ & $0.43 \pm 0.01$ \\
\hline 12 & $9.31 \pm 0.07 *$ & $10.67 \pm 0.42 *$ & $6.78 \pm 0.14$ & $3.14 \pm 0.34 * *$ & $3.17 \pm 0.06^{* *}$ & $1.68 \pm 0.07$ & $9.48 \pm 0.31 *$ & $10.65 \pm 0.02 *$ & $5.54 \pm 0.01$ & $0.75 \pm 0.03 *$ & $0.86 \pm 0.16^{*}$ & $0.42 \pm 0.00$ \\
\hline 24 & $8.72 \pm 0.06^{*}$ & $9.78 \pm 0.14 *$ & $6.75 \pm 0.17$ & $2.14 \pm 0.16$ & $2.70 \pm 0.49 *$ & $1.72 \pm 0.05$ & $7.47 \pm 0.23^{*}$ & $8.40 \pm 0.32 *$ & $5.352 \pm 0.01$ & $0.62 \pm 0.01 *$ & $0.72 \pm 0.09^{*}$ & $0.42 \pm 0.01$ \\
\hline 48 & $7.55 \pm 0.04 *$ & $7.74 \pm 0.03 *$ & $6.56 \pm 0.36$ & $1.92 \pm 0.03^{*}$ & $2.13 \pm 0.02 *$ & $1.60 \pm 0.15$ & $7.25 \pm 0.02 *$ & $7.81 \pm 0.02 *$ & $5.41 \pm 0.10$ & $0.53 \pm 0.01 *$ & $0.62 \pm 0.10^{*}$ & $0.41 \pm 0.01$ \\
\hline 72 & $7.43 \pm 0.15^{*}$ & $7.64 \pm 0.04 *$ & $6.63 \pm 0.40$ & $1.91 \pm 0.02$ & $2.12 \pm 0.04$ & $1.63 \pm 0.17$ & $6.84 \pm 0.28^{*}$ & $7.54 \pm 0.01 *$ & $5.46 \pm 0.16$ & $0.52 \pm 0.01$ & $0.58 \pm 0.05$ & $0.42 \pm 0.01$ \\
\hline 96 & $7.41 \pm 0.12$ & $7.62 \pm 0.06$ & $6.28 \pm 0.50$ & $1.85 \pm 0.20$ & $2.06 \pm 0.01$ & $1.57 \pm 0.21$ & $6.72 \pm 0.04$ & $7.50 \pm 0.01$ & $5.38 \pm 0.13$ & $0.52 \pm 0.01$ & $0.58 \pm 0.06$ & $0.42 \pm 0.01$ \\
\hline
\end{tabular}

$* \mathrm{P}<0.05, * * \mathrm{P}<0.001$

Table 5: Changes in Catalase activity in Fish tissues

(Values are Mean \pm S.D, $n=6$ )

\begin{tabular}{|c|c|c|c|c|c|c|c|c|c|c|c|c|}
\hline \multirow{3}{*}{$\begin{array}{c}\text { Time interval } \\
\text { (Hours) }\end{array}$} & & \multicolumn{11}{|c|}{ Catalace activity ( micromoles of $\mathrm{H} 2 \mathrm{o} 2$ decomposed $/ \mathrm{mg}$ protein/minute) } \\
\hline & & Liver & & & Gill & & & Kidney & & & Brain & \\
\hline & $\mathrm{T} 1$ & $\mathrm{~T} 2$ & Control & $\mathrm{T} 1$ & $\mathrm{~T} 2$ & Control & $\mathrm{T} 1$ & $\mathrm{~T} 2$ & Control & $\mathrm{T} 2$ & $\mathrm{~T} 2$ & Control \\
\hline 0 & $11.32 \pm 0.87$ & $12.25 \pm 0.33$ & $10.19 \pm 0.15$ & $13.09 \pm 0.37 * *$ & $13.29 \pm 0.55^{*}$ & $12.29 \pm 0.31$ & $8.74 \pm 1.189^{*}$ & $9.32 \pm 0.63 *$ & $7.33 \pm 0.14$ & $6.98 \pm 0.01 *$ & $7.00 \pm 0.21 *$ & $5.79 \pm 0.59$ \\
\hline 12 & $11.50 \pm 0.92 *$ & $12.27 \pm 0.24 *$ & $10.19 \pm 0.13$ & $12.91 \pm 0.45^{*}$ & $13.54 \pm 0.49 * *$ & $12.29 \pm 0.31$ & $8.92 \pm 1.026^{*}$ & $9.50 \pm 0.48^{*}$ & $7.36 \pm 0.15$ & $6.78 \pm 0.162 * *$ & $7.08 \pm 0.20 *$ & $5.78 \pm 0.60$ \\
\hline 24 & $11.32 \pm 0.96 * *$ & $11.61 \pm 0.75 *$ & $10.18 \pm 0.11$ & $12.86 \pm 0.72 *$ & $13.20 \pm 0.30 *$ & $12.27 \pm 0.29$ & $9.21 \pm 0.926 * *$ & $9.20 \pm 1.00 * *$ & $7.34 \pm 0.14$ & $6.85 \pm 0.39 *$ & $7.06 \pm 0.11 *$ & $5.78 \pm 0.59$ \\
\hline 48 & $10.62 \pm 1.03 *$ & $10.79 \pm 0.63 *$ & $10.18 \pm 0.99$ & $11.86 \pm 0.03$ & $12.46 \pm 0.019^{*}$ & $12.30 \pm 0.31$ & $7.86 \pm 0.026^{*}$ & $7.64 \pm 0.032 *$ & $7.36 \pm 0.15$ & $6.265 \pm 0.124 *$ & $6.66 \pm 0.22 *$ & $5.75 \pm 0.60$ \\
\hline 72 & $9.98 \pm 0.840^{*}$ & $10.13 \pm 0.33^{*}$ & $10.19 \pm 0.55$ & $11.8 \pm 0.77$ & $12.45 \pm 0.35$ & $12.29 \pm 0.31$ & $7.79 \pm 0.019 *$ & $7.61 \pm 0.024$ & $7.34 \pm 0.14$ & $6.22 \pm 0.012$ & $6.62 \pm 0.033^{*}$ & $5.74 \pm 0.61$ \\
\hline
\end{tabular}

Table 6: Changes in Glutathione peroxidase activity in fish tissues

(Values are Mean \pm S.D, $\mathrm{n}=6$ )

\begin{tabular}{|c|c|c|c|c|c|c|c|c|c|c|c|c|}
\hline \multirow{3}{*}{$\begin{array}{l}\text { Time } \\
\text { interval } \\
\text { (Hours) }\end{array}$} & \multicolumn{12}{|c|}{ Glutathione peroxidase activity ( micromoles of NADH oxidised $/ \mathrm{mg}$ protein/min) } \\
\hline & & Liver & & & Gill & & & Kidney & & & Brain & \\
\hline & $\mathrm{T} 1$ & $\mathrm{~T} 2$ & Control & $\mathrm{T} 1$ & $\mathrm{~T} 2$ & Control & $\mathrm{T} 1$ & $\mathrm{~T} 2$ & Control & $\mathrm{T} 2$ & $\mathrm{~T} 2$ & Control \\
\hline 0 & $6.8 \pm 0.08 *$ & $7.63 \pm 0.847 *$ & $5.84 \pm 0.149$ & $3.64 \pm 0.462 *$ & $3.5 \pm 0.52 *$ & $2.97 \pm 0.01$ & $1.00 \pm 0.171 *$ & $1.08 \pm 0.10 *$ & $0.59 \pm 0.01$ & $0.29 \pm 0.01 *$ & $0.195 \pm 0.023^{*}$ & $0.107 \pm 0.027$ \\
\hline 12 & $6.90 \pm 0.394 *$ & $7.99 \pm 0.842 *$ & $5.84 \pm 0.164$ & $3.69 \pm 0.44 *$ & $3.52 \pm 0.52 *$ & $2.97 \pm 0.02$ & $1.09 \pm 0.01 * *$ & $1.05 \pm 0.018 *$ & $0.59 \pm 0.01$ & $0.29 \pm 0.04 *$ & $0.217 \pm 0.029 *$ & $0.112 \pm 0.030$ \\
\hline 24 & $6.93 \pm 0.23 *$ & $6.82 \pm 0.633$ & $5.84 \pm 0.153$ & $3.44 \pm 0.275^{*}$ & $3.44 \pm 0.02 *$ & $2.97 \pm 0.02$ & $1.05 \pm 0.01 *$ & $0.99 \pm 0.02 *$ & $0.59 \pm 0.01$ & $0.242 \pm 0.427 *$ & $0.195 \pm 0.034 *$ & $0.122 \pm 0.027$ \\
\hline 48 & $6.35 \pm 0.02 *$ & $6.76 \pm 0.561 *$ & $5.84 \pm 0.15$ & $3.09 \pm 0.15$ & $3.03 \pm 0.01$ & $2.97 \pm 0.02$ & $1.085 \pm .0 .02 *$ & $0.78 \pm 0.01$ & $0.58 \pm 0.03$ & $0.19 \pm 0.012 *$ & $0.15 \pm 0.02 *$ & $0.11 \pm 0.08$ \\
\hline 72 & $6.33 \pm 0.018 *$ & $6.78 \pm 0.02 *$ & $5.84 \pm 0.01$ & $3.02 \pm 0.012$ & $2.93 \pm 0.49$ & $2.96 \pm 0.01$ & $0.84 \pm 0.02 *$ & $0.77 \pm 0.015$ & $0.58 \pm 0.017$ & $0.187 \pm 0.047^{*}$ & $0.142 \pm 0.017 *$ & $0.115 \pm 0.02$ \\
\hline
\end{tabular}

Table 7: Changes in Glutathione S-Transferase activity in fish tissues

(Values are Mean \pm S.D, $n=6$ )

\begin{tabular}{|c|c|c|c|c|c|c|c|c|c|c|c|c|}
\hline \multirow{3}{*}{$\mid \begin{array}{c}\text { Time interval } \\
\text { (Hours) }\end{array}$} & \multicolumn{12}{|c|}{ Glutathione S-Transferase activity (micromoles of thioether formed $/ \mathrm{mg}$ protein $/ \mathrm{min}$ ) } \\
\hline & & Liver & & & Gill & & & Kidney & & & Brain & \\
\hline & $\mathrm{T} 1$ & $\mathrm{~T} 2$ & Control & $\mathrm{T} 1$ & $\mathrm{~T} 2$ & Control & $\mathrm{T} 1$ & $\mathrm{~T} 2$ & Control & $\mathrm{T} 2$ & $\mathrm{~T} 2$ & Control \\
\hline 0 & $3.77 \pm 0.17 *$ & $3.88 \pm 0.53 *$ & $3.05 \pm 0.02$ & $0.822 \pm 0.08 *$ & $0.91 \pm 0.07 *$ & $0615 \pm 0.02$ & $3.005 \pm 0.64 *$ & $3.062 \pm 0.10^{*}$ & $21.12 \pm 0.01$ & $0.24 \pm 0.04 *$ & $0.33 \pm 0.02 *$ & $0.172 \pm 0.05$ \\
\hline 12 & $3.77 \pm 0.37 *$ & $3.98 \pm 0.60 *$ & $3.05 \pm 0.04$ & $0.86 \pm 0.08^{* *}$ & $0.942 \pm 0.05^{*}$ & $0.617 \pm 0.01$ & $3.05 \pm 0.64 *$ & $3.305 \pm 0.24 *$ & $2.12 \pm 0.01$ & $0.26 \pm 0.02 *$ & $0.37 \pm 0.02 *$ & $0.175 \pm 0.39$ \\
\hline 24 & $3.55 \pm 0.39 *$ & $3.95 \pm 0.58 *$ & $3.06 \pm 0.04$ & $0.85 \pm 0.04 *$ & $0.89 \pm 0.04 *$ & $0.622 \pm 0.00$ & $3.12 \pm 0.75^{* *}$ & $3.365 \pm 0.18^{*}$ & $2.11 \pm 0.02$ & $0.26 \pm 0.03 *$ & $0.33 \pm 0.01 *$ & $0.167 \pm 0.04$ \\
\hline 48 & $3.18 \pm 0.05^{*}$ & $3.28 \pm 0.00^{*}$ & $3.05 \pm 0.02$ & $0.747 \pm 0.00 *$ & $0.732 \pm 0.02 *$ & $0.617 \pm 0.01$ & $2.47 \pm 0.06^{*}$ & $2.64 \pm 0.03^{* *}$ & $2.31 \pm 0.05$ & $0.19 \pm 0.01 *$ & $0.25 \pm 0.01^{*}$ & $0.17 \pm 0.05$ \\
\hline 72 & $3.17 \pm 0.03 *$ & $3.12 \pm 0.02 *$ & $3.06 \pm 0.02$ & $0.722 \pm 0.05^{*}$ & $0.722 \pm 0.01 *$ & $0.627 \pm 0.00$ & $2.36 \pm 0.03 *$ & $2.64 \pm 0.18^{*}$ & $2.12 \pm 0.01$ & $0.17 \pm 0.03^{*}$ & $0.23 \pm 0.02 *$ & $0.172 \pm 0.04$ \\
\hline 96 & $3.14 \pm 0.02$ & $3.09 \pm 0.005$ & $3.06 \pm 0.04$ & $0.71 \pm 0.00 *$ & $0.702 \pm 0.01$ & $0.62 \pm 0$ & $2.34 \pm 0.03$ & $2.487 \pm 0.02 *$ & $2.13 \pm 0.03$ & $0.17 \pm 0.01 *$ & $0.21 \pm 0.02 *$ & $0.178 \pm 0.06$ \\
\hline
\end{tabular}

\section{Volume 5 Issue 6, June 2016 www.ijsr.net}

Licensed Under Creative Commons Attribution CC BY 